\title{
Effect of human granulocyte macrophage-colony stimulating factor on differentiation and apoptosis of the human osteosarcoma cell line SaOS-2
}

\author{
L. Postiglione, G. Di Domenico, G. Giordano-Lanza*, P. Ladogana, M. Turano, C. Castaldo*, \\ F. Di Meglio*, S. Cocozza, S. Montagnani* \\ Dipartimento di Scienze Biomorfologiche e Funzionali; *Dipartimento di Biologia e Patologia Cellulare e \\ Molecolare "L. Califano", Università degli Studi "Federico II", Naples, Italy
}

\begin{abstract}
(C)2003, European Journal of Histochemistry
We investigated the effects of human granulocyte macrophage-colony stimulating factor (GM-CSF) on the relation between differentiation and apoptosis in SaOS-2 cells, an osteoblast-like cell line. To determine the relationship between these cellular processes, SaOS-2 cells were treated in vitro for 1,7 and 14 days with $200 \mathrm{ng} / \mathrm{mL}$ GM-CSF and compared with untreated cells. Five nM insulin-like growth factor (IGF-I) and $30 \mathrm{nM}$ okadaic acid were used as negative and positive controls of apoptosis, respectively. Effects on cell differentiation were determined by ECM (extracellular matrix) mineralization, morphology of some typical mature osteoblast differentiation markers, such as osteopontin and sialoprotein II (BSP-II), and production of bone ECM components such as collagen I. The results showed that treatment with GM-CSF caused cell differentiation accompanied by increased production of osteopontin and BSP-II, together with increased ECM deposition and mineralization. Flow cytometric analysis of annexin $\mathrm{V}$ and propidium iodide incorporation showed that GM-CSF up-regulated apoptotic cell death of SaOS-2 cells after 14 days of culture in contrast to okadaic acid, which stimulated SaOS-2 apoptosis only during the early period of culture. Endonucleolytic cleavage of genomic DNA, detected by "laddering analysis", confirmed these data. The results suggest that GM-CSF induces osteoblastic differentiation and long-term apoptotic cell death of the SaOS-2 human osteosarcoma cell line, which in turn suggests a possible in vivo physiological role for GM-CSF on human osteoblast cells.
\end{abstract}

Key words: GM-CSF, ostesarcoma cells, apoptosis.

Correspondence: Prof. Stefania Montagnani, Sezione di Anatomia Umana e Istologia, Dipartimento di Scienze Biomorfologiche e Funzionali, via Pansini 5, 80131 Naples, Italy. Phone: international +39.081.7463419. Fax. international +39.081.5469803. E-mail: montagna@unina.it

Paper accepted on April 16, 2003

European Journal of Histochemistry

2003; vol. 47 issue 4 [Oct-Dec]: 309-316
$\mathrm{H}$ uman granulocyte macrophage-colony stimulating factor (GM-CSF) is a major cytokine active on hematopoietic cells at different stages (Aglietta et al., 1991; Abbas et al., 1991; Kittler et al., 1992). It induces a large variety of biological effects, such as proliferation and differentiation of myeloid and CD34-positive progenitors (Metcalf, 1989; Nishijima et al., 1995). Recent evidences indicate that GM-CSF is active also on a variety of cell types of non-hematopoietic origin, such as keratinocytes, solid tumor lines, bone marrow fibroblasts and endothelial cells (Dedhar et al., 1988; Colotta et al., 1993; Bussolino et al., 1991). It exerts different effects on normal cell growth and development through a receptor-mediated process (Ruff et al., 1986; Schmitz et al., 1995).

Apoptosis, or physiological cell death, is representative of an endogenous cell suicide mechanism which can be selectively triggered by cells in response to stimuli still largely unknown (Willie et al., 1980; Green, 2000). This phenomenon is mediated by various types of proteins, among which there is the Bcl-2 family. This family can be divided into three subgroups. The members of the first subgroup, represented by $\mathrm{Bcl}-2$ and $\mathrm{Bcl}-\mathrm{XL}$, have anti-apoptotic function; members of the second and third subgroups, respectively, represented by Bax and Bak, and Bid and Bad, are pro-apoptotic molecules. Apoptosis, furthermore, is mediated by another family of proteins called caspases, which are activated after their inactive precursor has been processed. Caspase- 9 and -8 are initiator caspases that are involved in mitochondrial-mediated and death domain-mediated apoptosis, respectively. Caspase-3, -6 and -7 function as effectors of apoptosis (Gottlieb, 2000).

During apoptosis, a series of well-defined degenerative changes occur within the cell (Duvall and Wylie, 1986) and ultimately result in the degradation of the nuclear DNA into oligonucleosome chains (Willie, 
1980) and the fragmentation of the cell into neat bite-size pieces which can be specifically recognized by macrophages and subsequently phagocytosed (Duvall et al., 1985, Savill et al., 1989, Fadok et al., 1992). Hematopoietic cytokines, such as interleukin3 (IL-3) and GM-CSF, can prevent apoptosis of hematopoietic cells by activating a specific signalling pathway distinct from that of cell proliferation (Kinoshita et al., 1995). Nevertheless, the effects of GM-CSF on apoptosis of non-hematopoietic cells are not well known (Muto et al., 2001).

A few years ago, Rodan et al. (1987) characterized a new human osteosarcoma cell line, called SaOS-2. Using these cells, a set of properties which seemed to be associated with a well differentiated osteoblastic phenotype, such as elevated levels of alkaline phosphatase and parathyroid hormonestimulated adenylate cyclase, and synthesis and secretion of type I collagen, was established in vitro.

Recent data have shown that the SaOS-2 cell line is able to secrete GM-CSF, leading to questions concerning the biological significance of the presence of this growth factor on the cell membrane, and the presence of the cytokine on the extra-cellular matrix (ECM) (Taichman et al., 1996). In a previous paper, we showed that SaOS-2 cells expressed GM-CSF receptors, and that GM-CSF was able to regulate the proliferation and differentiation of these cells. In fact, during treatment with GM-CSF, SaOS-2 cells increased their production of bone ECM collageneous and non-collageneous components. Furthermore, GM-CSF appeared to be able to regulate, after 14 days of culture, cell differentiation of SaOS-2 cells through stimulation of alkaline phosphatase activity. On the contrary, the effect of the cytokine on cell growth was anti-proliferative (Postiglione et al., 2003).

In the present study, we investigated the effects of GM-CSF on some ECM structures known to be involved in mineralization of bone tissue, such as osteopontin and sialoprotein II (BSP-II), two noncollagenous hydroxyapatite crystal-binding proteins produced mainly during the late stages of osteoblastic differentiation (Kasugai et al., 1992). Furthermore, we investigated the synthesis of collagen I, the major specific component of bone connective tissue produced by osteoblasts during differentiation (Owen et al., 1990). The synthesis of collagen I was also modulated by GM-CSF (Postiglione et al., 2003), which may confirm that SaOS-2 cell differentiation, under GM-CSF stimulation, goes toward a typically mature osteoblastic phenotype.

Since it is well known that various types of cells can be induced to undergo apoptosis when they achieve a terminal step of differentiation and maturation (Martin et al., 1990), we analysed the biological effects of GM-CSF on differentiation and apoptosis of the SaOS-2 cells in vitro. Our purpose was to investigate whether the treatment with this cytokine can modulate the SaOS-2 apoptotic pathway, probably through inhibition of cell growth, in addition to an influence on their maturation stage.

Insulin-like growth factor (IGF-I), which has an anti-apoptotic effect on SaOS-2 cells (Schmid et al., 1999), was used as a negative control of apoptosis, while okadaic acid, an inhibitor of protein phosphatases 1 and 2A (Shenolikar, 1995), was used as a positive control.

\section{Materials and Methods Cell culture}

The human osteosarcoma cell line SaOS-2 (ATCC85-HTB) was cultured in Dulbecco's modified Eagles medium (DMEM) (Sigma, St. Louis, M0, USA), with $10 \%$ heat-inactivated FCS (Gibco, Grand Island, NY, USA), 2 mM L-glutamine, 10 $\mathrm{U} / \mathrm{mL}$ penicillin and $0.1 \mathrm{mg} / \mathrm{mL}$ streptomycin (Sigma) in a humidified incubator at $37^{\circ} \mathrm{C}$ under an $95 \%$ air $/ 5 \% \mathrm{CO}_{2}$ mixture. Medium was changed every 3-4 days. Cells were detached by $0.5 \mathrm{mM}$ EDTA in calcium- and magnesium-free phosphatebuffered saline (PBS) with $0.05 \%$ trypsin.

\section{"In vitro" treatment of cell cultures}

Human recombinant GM-CSF $(300 \mu \mathrm{g} / \mathrm{mL})$ was used (Schering Plough, County Cork, IR). SaOS-2 cells were cultured adding 10, 100 and $200 \mathrm{ng} / \mathrm{mL}$ of GM-CSF to the culture medium. In other SaOS2 cell cultures, $30 \mathrm{nM}$ okadaic acid (Sigma) was used as a positive control and 5 nM IGF-1 (Sigma) was used as a negative control of apoptosis.

Freshly prepared amounts of GM-CSF, at the same concentrations, were added every three days.

\section{Cytochemistry}

For cytochemical analysis, GM-CSF-stimulated and unstimulated SaOS-2 cells were plated, grown on glass coverslips, and stained with the Von Kossa method modified for cell culture (Postiglione et al., 2003) after 1,7 and 14 days of culture. Briefly, cells were fixed for 3 min with $3 \%$ formaldehyde in PBS, washed twice in PBS, covered with a $0.5 \%$ aqueous 
solution of silver nitrate and exposed to UV light (Philips, 30W) for $30 \mathrm{~min}$ at $25^{\circ} \mathrm{C}$. Coverslips were then washed with distilled water and treated with $5 \% \mathrm{Na}_{2} \mathrm{SO}_{4}$. After washing in tap water, coverslips were covered with $1 \%$ neutral red to stain nuclei and then submitted to the routine passages in alcohol, xylene and mounting medium.

All microscope evaluations were made on a LEICA DM LB equipped for microphotography by three independent observers and expressed on a five points arbitrary scale, ranging from negative $(0)$ to very abundant $(++++$, i.e. over $60 \%$ of the cells).

\section{Immunocytochemistry}

GM-CSF-stimulated and unstimulated SaOS-2 cells were plated and grown on glass coverslips and fixed after 1, 7 and 14 days of culture with 3\% formaldehyde in PBS for 3 min at room temperature. The cells were then gently washed twice with PBS and incubated with monoclonal IgG antibodies against human osteopontin or BSP-II (University of Iowa, Iowa City, USA), or with monoclonal antihuman collagen I (Sigma). After three further washes with PBS, the cells were stained with rhodamine or fluorescein-labeled rabbit anti-mouse IgG. The same coverslips were contemporaneously incubated with fluorescein or rhodamine-tagged phalloidin, in order to delineate cell morphology by actin visualization. Both steps required 1 hour incubation at $37^{\circ} \mathrm{C}$ in a humidified chamber. Coverslips were then mounted with Moviol and observed with a LEICA DM LB equipped for epifluorescence and microphotography. When needed, the coverslips were treated with Triton $\mathrm{X} 100$ buffer $(20 \mathrm{mM}$ HEPES, $300 \mathrm{mM}$ sucrose, $50 \mathrm{mM} \mathrm{NaCl}, 3 \mathrm{mM}$ $\mathrm{MgCl}_{2}, 0.5 \%$ Triton X100, $\mathrm{pH} 7.4$ ) in order to permeabilize the cells before the primary antibody step, and then processed as described (Polak and Van Noorden, 1992). Each sample was evaluated by three independent observers, using a four point arbitrary scale, ranging from 0 to 3 .

\section{Flow cytometric analysis}

SaOS-2 cells were plated in $60 \mathrm{~mm}$ Petri dishes at different density $\left(10 \times 10^{3}\right.$ at 1 day; $70 \times 10^{3}$ at 7 days; $30 \times 10^{3}$ at 14 days) to ensure a confluence of $75 \%$ of the cells for each experimental point. Cells were harvested by trypsinization and centrifuged at $1500 \mathrm{rpm}$ for $5 \mathrm{~min}$. The pellet was stained with the apoptotic detection kit Annexin-V-FLUOS (Roche, Mannheim, Germany). This method is based on the simultaneous staining of cell surface phosphatidylserine (with Annexin-V-FLUOS-green dye), and necrotic cells (with propidium iodide). Exclusion of propidium iodide, coupled with binding of Annexin-V-FLUOS, indicates the percentage of apoptotic cells. The procedure involved the staining of the pelleted cells in a solution containing Annexin-V-FLUOS and propidium iodide and an incubation of $15 \mathrm{~min}$ at room temperature. Cells were then washed twice in PBS and analysed by flow cytometry using a FACScan (Becton Dickinson, Mountain View, $\mathrm{Ca}$, USA) at wavelengths of 530-570 nm. Flow cytometric measurement of 100,000 events was performed and apoptotic analysis was executed by CELL LYSIS software.

For intracytoplasmic Bcl-2 detection, the Fix and Perm kit (Caltag, Burlingame, CA) was used. This procedure gives to the antibodies access to intracellular structures, preserving at the same time the morphological scatter characteristics of cells. The method involves a sequential reaction with a fixing solution followed by a permeabilizating one; finally, direct immunofluorescence using a monoclonal FITC antibody (mAb) against Bcl-2 (Caltag) was performed. Nonspecific anti-mouse FITC IgG was used as a control (Sigma). The fluorescence intensity of the cell suspensions was measured by flow cytometry using a FACScan (Becton Dickinson) at the wavelengths of 530-570 nm and the mean fluorescence intensity values on the scatter dot plot of the apoptotic and non-apoptotic cell populations were evaluated. Each experiment was repeated three times.

\section{DNA isolation and electrophoresis}

Cells were lysed in $0.5 \%$ Triton X100, $40 \mathrm{mM}$ Tris, pH 7.4 and $0.1 \mathrm{mM}$ EDTA. After spinning in a microfuge at $4^{\circ} \mathrm{C}$ for $20 \mathrm{~min}$, the soluble fraction was extracted twice with an equal volume of a $1: 1$ phenol:chloroform mixture. Soluble DNA was precipitated by the addition of 2.5 volumes of ethanol and $300 \mathrm{mM} \mathrm{NaCl}$. DNA was separated on a 1.5\% agarose gel.

\section{Statistical analysis}

The difference between the mean intensity results of the flow cytometric analysis of treated and untreated cells was analyzed by the Student's t-test for paired samples. Results were considered significant at $p<0.05$. 


\section{Results}

\section{Cytochemistry}

The deposition of calcified ECM by SaOS2 cells as determined by the Von Kossa method clearly demonstrated an increase of calcium precipitates in the ECM: this effect was evident as early as 72 hours in culture (Table 1) and became more evident during the following days at high cytokine concentrations. In some samples, the deposition of calcium precipitates strictly adherent to the cell membrane of SaOS-2 cells became evident after one week in culture at the highest GM-CSF concentration (Figure 1).

\section{Immunocytochemistry}

Immunofluorescence analysis demonstrated that GM-CSF was able to induce the expression of mineralization markers in SaOS-2 cells. It is interesting to note that osteopontin became evident very early in some SaOS-2 cells treated with high concentrations of GM-CSF. However, while in the early days of culture the marker appeared both in the cytoplasm
Table 1. Calcium deposition in GM-CSF-treated SaOS-2 cells. The Von Kossa method demonstrates an increase in calcium precipitates in the ECM which becomes more evident at longer times of culture at high concentrations of the cytokine.

\begin{tabular}{lcccc} 
Time of treatment & Control & $\begin{array}{c}\text { GM-CSF } \\
(10 \mathrm{ng} / \mathrm{mL})\end{array}$ & $\begin{array}{c}\text { GM-CSF } \\
(100 \mathrm{ng} / \mathrm{mL})\end{array}$ & $\begin{array}{c}\text { GM-CSF } \\
(200 \mathrm{ng} / \mathrm{mL})\end{array}$ \\
\hline $24 \mathrm{~h}$ & ++ & + & ++ & ++ \\
$7 \mathrm{~d}$ & ++ & +++ & +++ & +++ \\
$14 \mathrm{~d}$ & +++ & +++ & +++ & ++++
\end{tabular}

and on the membrane, after a few days it was expressed mainly on the cell membrane (Figure 2, A and B). The GM-CSF-induced differentiation of SaOS-2 cells in a more mature phenotype was confirmed by the concentration- and time-dependent increases in the synthesis of BSP-II, a non-collagenous protein, involved in bone matrix deposition (Figure 2, C and D).

As regards the production of collagen I, morpho-
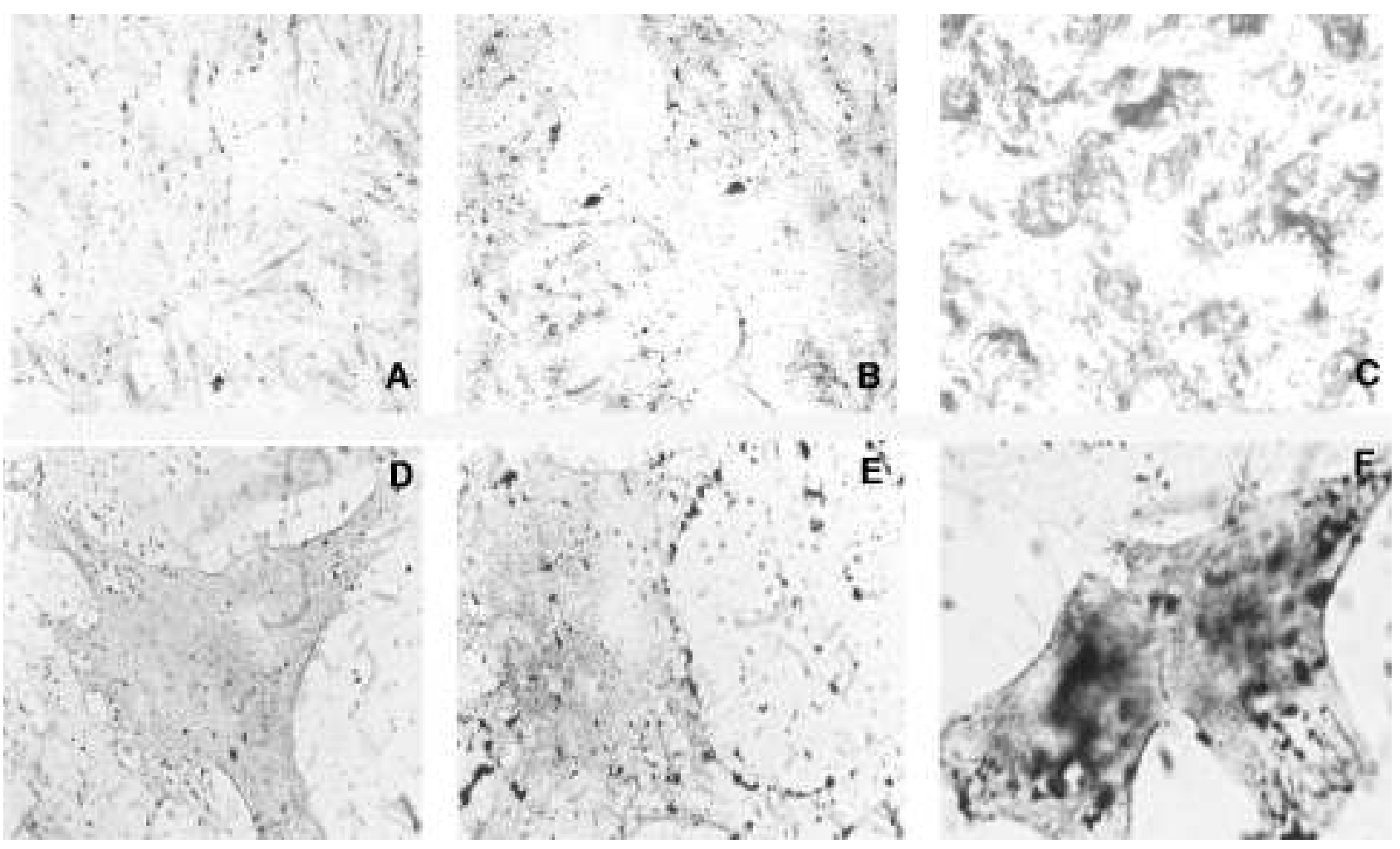

Figure 1. Effects of GM-CSF on ECM mineralization. Stimulated and unstimulated SaOS-2 cells were stained by the Von Kossa method modified for cell culture. After 14 days of culture, the Von Kossa staining evidences: A) a light deposition of calcium in basal conditions; B) enhanced presence of calcium precipitates in Sa0S-2 cultures treated with $100 \mathrm{ng} / \mathrm{mL}$ of GM-CSF and C) a further increase in calcium deposition in SaOS-2 cultures treated with $200 \mathrm{ng} / \mathrm{mL}$ of GM-CSF. D), E) and F) are more detailed pictures from similar fields. As evidenced, Von Kossa-positive granules are more abundant with increasing concentration of GM-CSF. A-C) Magnification 100X; D-F) Magnification 1000X. 

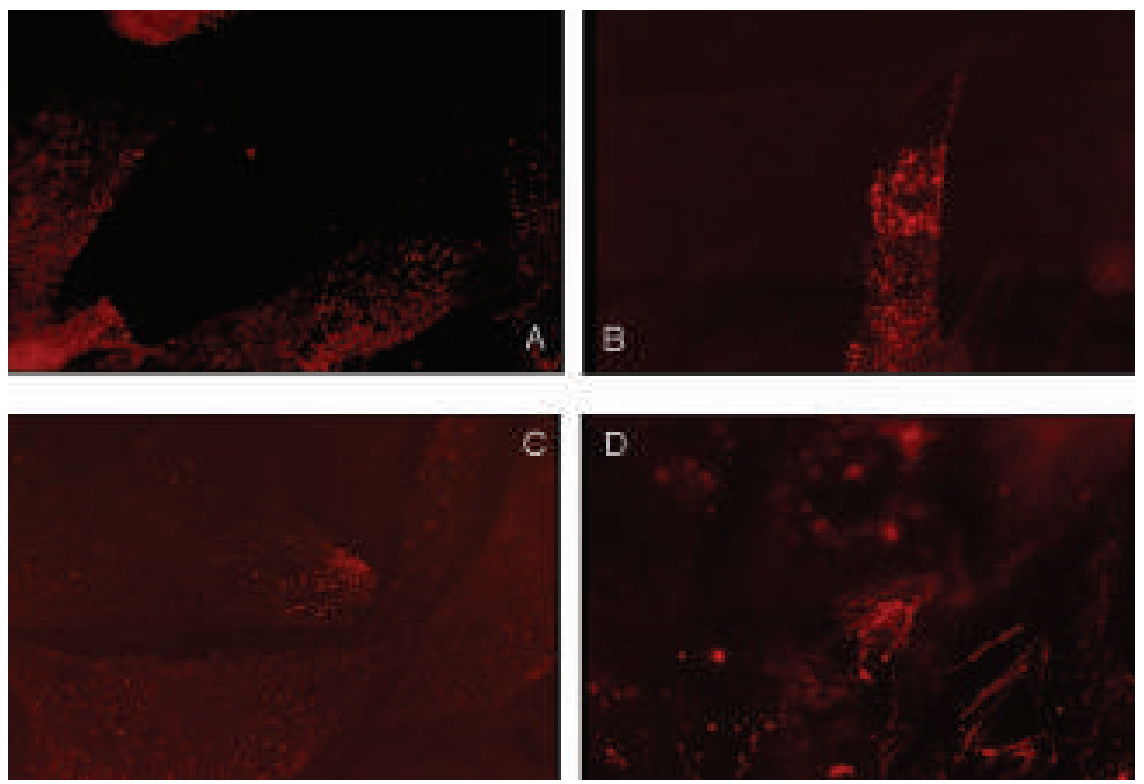

Figure 2. Effects of GM-CSF on the synthesis of non-collagenous protein involved in bone deposition. Immunocytochemistry demonstrates that GM-CSF increased the expression of mineralization markers such as osteopontin (A, untreated and B, treated SaOS-2 cells) and BSP-II, (C, untreated and $D$, treated cells). Magnification 1000X logical analysis demonstrated the presence of collagen fibers (Figure 3) around both the unstimulated and the GM-CSF treated cells, with an increase during the last period of culture after GM-CSF addition.

\section{Flow cytometric analysis}

To determine whether GM-CSF can affect cell apoptosis of SaOS-2, we examined these cells by flow cytometric analysis after 1, 7 and 14 days of culture, after treatment with $200 \mathrm{ng} / \mathrm{mL}$ of $\mathrm{GM}$ CSF. No significant difference was found either in the GM-CSF- or the IGF-1-stimulated SaOS-2 cells after 1 and 7 days of culture, as compared to unstimulated ones ( $p>0.05$ ). Moreover, GM-CSF significantly doubled annexin $V$ incorporation ( $p$ $<0.03)$ and propidium iodide $(p<0.04)$ staining after 14 days of culture, while no significant difference was found in annexin- $V$ incorporation induced by IGF-I, as compared with the unstimulated cells ( $p>0.05$ ) (Table 2).

Okadaic acid induced a statistically significant 25 fold increase in cell apoptosis when compared to the unstimulated cells after $7(p<0.02)$ and 14 ( $p$ $<0.03$ ) days of culture (Table 2 ).

In order to determine if apoptosis of SaOS-2 cells was mediated by $\mathrm{Bcl}-2$ down-regulation, intracytoplasmatic $\mathrm{Bcl}-2$ protein was measured. Only minimal differences in the mean fluorescence intensity of $\mathrm{Bcl}-2$ protein were observed, which were not statistically significant $(p>0.05)$ in the SaOS-2 cells treated with GM-CSF, IGF-1 or okadaic acid, as
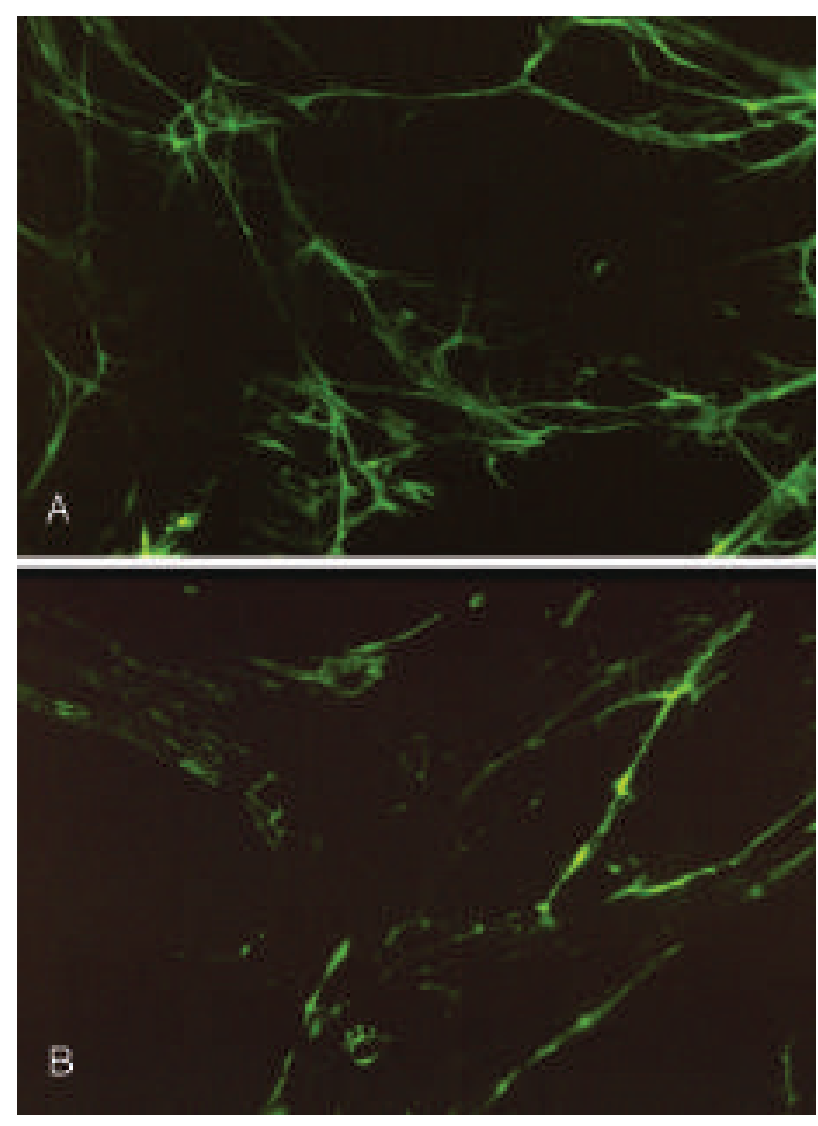

Figure 3. Effects of GM-CSF on SaOS-2 production of collagen I, another bone ECM component: the presence of collagen fibers is more evident in GM-CSF treated cells, with an increase after 14 days of culture $(A)$ when compared with unstimulated cells (B). Magnification 1000X 
Table 2. Flow cytometric analysis of apoptosis in Sa0S-2 cells. Values are represented as Mean Intensity \pm SD at each time point of three independent experiments. The percentage of expression is shown in parentheses.

\begin{tabular}{|c|c|c|c|c|c|c|c|c|c|}
\hline \multirow[b]{2}{*}{ Treatment } & \multicolumn{3}{|c|}{1 day } & \multicolumn{3}{|c|}{7 days } & \multicolumn{3}{|c|}{14 days } \\
\hline & P.l. & Ann.V & $B C l-2$ & P.l. & Ann.V & $B C l-2$ & P.l. & Ann.V & $B C l-2$ \\
\hline Unstimulated & $1197 \pm 10(13 \%)$ & $2053 \pm 20(14 \%)$ & $182 \pm 10(50 \%)$ & $3081 \pm 20(50 \%)$ & $228 \pm 10(2 \%)$ & $243 \pm 10(50 \%)$ & $1336 \pm 14(19 \%)$ & $111 \pm 7(4 \%)$ & $241 \pm 10(54 \%)$ \\
\hline +IGF (15 nM) & $847 \pm 15(9 \%)$ & $2378 \pm 25(15 \%)$ & $168 \pm 15(44 \%)$ & $2026 \pm 18(18 \%)$ & $251 \pm 10(2 \%)$ & $231 \pm 15(55 \%)$ & $1214 \pm 19(7 \%)$ & $180 \pm 5(5 \%)$ & $229 \pm 15(57 \%)$ \\
\hline +0kadaic acid (30 nM) & $1430 \pm 15(15 \%)$ & $3465 \pm 30(27 \%)$ & $180 \pm 7(50 \%)$ & $1961 \pm 20(45 \%)$ & $1435 \pm 15 *(47 \%)$ & $337 \pm 20(50 \%)$ & $3115 \pm 20 *(45 \%)$ & $631 \pm 10 *(43 \%)$ & $256 \pm 19(44 \%)$ \\
\hline +GM-CSF (200 ng/mL) & $1360 \pm 18(14 \%)$ & $1655 \pm 20(9 \%)$ & $179 \pm 10(48 \%)$ & $3008 \pm 25(50 \%)$ & $223 \pm 10(2 \%)$ & $218 \pm 10(44 \%)$ & $2873 \pm 20 *(39 \%)$ & $242 \pm 5 *(8 \%)$ & $210 \pm 10(50 \%)$ \\
\hline
\end{tabular}

${ }^{*} p<0.05$ versus the unstimulated SaOS-2 cells. No significant difference was found either in GM-CSF or IGF-1 stimulated and unstimulated SaOS- 2 cells after 1 and 7 days of culture. GM-CSF doubled the annexin V incorporation and propidium iodide staining after 14 days of culture, while no significant difference was found in IGF-I induced annexin-V incorporation. Okadaic acid induced an increase of cell apoptosis between 2-5 fold after 7 and 14 days of culture. Furthermore, treatment of SaOS-2 cells with GM-CSF, IGF-1 and okadaic acid produced no statistically significant difference in Bcl-2 protein expression during the whole period of culture.

compared to untreated cells. These results were noticed both for the apoptotic cells and the nonapoptotic cell fractions during the entire period of culture (Table 2).

\section{Electrophoretic detection of DNA fragmentation}

After 14 days of culture, GM-CSF and okadaic acid generated internucleosomal cleavage which formed a ladder DNA fragment, as is characteristic in cells undergoing programmed cell death. In contrast, only minimal DNA degradation products were detected in unstimulated SaOS-2 cells, or in IGF-I treated cultures (Figure 4).

\section{Discussion}

It is well known that GM-CSF has a variety of biological roles in both normal and tumor cells (Foulke et al., 1990) and previous studies demonstrated that it can suppress apoptosis in hematopoietic cells by activating a signalling pathway distinct from the induction of DNA synthesis (Kinsohita et al, 1995).

We recently reported that the human osteosarcoma SaOS-2 cell line expresses GM-CSF receptor and that GM-CSF can modulate cell differentiation of these cells, probably through the inhibition of cell growth (Postiglione et al, 2003). Several studies have demonstrated a sequence of growth, differentiation, maturation and apoptosis in human cells of different embryonic origin (Robbins et al., 1997; Le et al., 2002).

In this report, we examined whether GM-CSF was able to regulate cell differentiation and, at the same time, apoptosis in SaOS-2 cells, employing IGF-I as a negative control, and okadaic acid as a positive control of apoptosis.
Some morphofunctional aspects of bone cell cultures suggestive of a more mature state confirm that GM-CSF acts as a differentiative rather than a proliferative cytokine on these cells, as happens in other cell cultures. For example, the production of mineralized ECM seems to be promoted by GMCSF, as revealed by a time-dependent increase in $\mathrm{Ca}^{++}$precipitates in stimulated $\mathrm{SaOS}-2$ cells, with a more significant effect being observed at high GMCSF concentrations ( 100 and $200 \mathrm{ng} / \mathrm{mL}$ ) and after 14 days of culture. The increase in calcium precipitate deposition is one of the most specific and accepted markers of mineralized matrix production as a consequence of osteoblastic differentiation (Pockwinse et al., 1992). Thus, it is interesting to note the expression pattern of osteopontin, which is
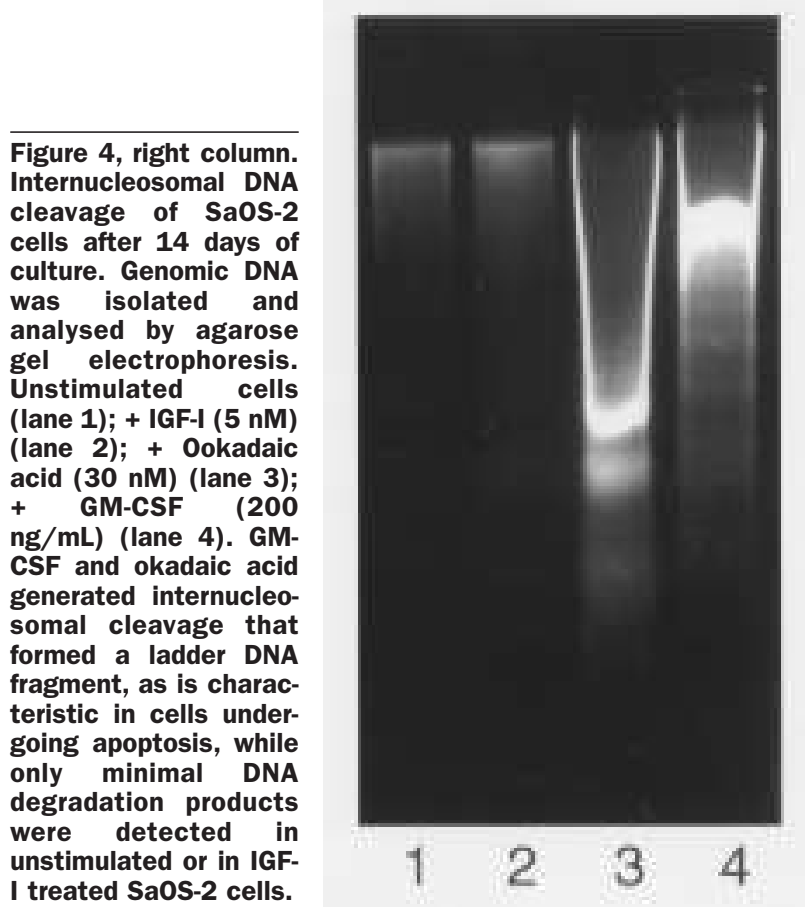
typical of mature bone tissue, and was known, until just a few years ago, only because it was expressed by osteoclasts in correspondence with the clear zone of the cell membrane, where cells adhere to the bone matrix and exert their remodelling action (Kasugai et $\mathrm{al}, 1992$ ). Osteopontin is currently considered to be a morphogenetic protein and is widely studied in many tissues, from heart (Graf et al, 1997) to mineralizing bone. The expression of osteopontin became evident very early on in some SaOS-2 cells treated with high concentrations of GM-CSF. However, while in the early days of culture this protein appeared both in the cytoplasm and on the membrane, it was, after a few days, expressed mainly on the cell membrane (Figure 2A). At the same time, BSP-II became lightly evident at 14 days of culture, with its production being increased in GMCSF treated cells.

Since a known characteristic of osteopontin and BSP-II is that they appear during the last stages of osteoblastic differentiation (Kasugai et al., 1992), the demonstration that SaOS-2 cells produced these two non-collagenous hydroxyapatite crystal-binding proteins at a late stage of culture ( 14 days), and that their production was increased under GM-CSF stimulation, confirms that GM-CSF triggered SaOS-2 cell differentiation toward a typically more mature osteoblastic phenotype.

The synthesis of collagen I, the major specific component of bone connective tissue produced by osteoblasts during differentiation, also seems to be positively modulated by GM-CSF, increasing between 7 and 14 days of culture at 100 and 200 $\mathrm{ng} / \mathrm{mL}$. In fact, here we showed that GM-CSF-treated SaOS-2 cells produced collagen I from the early days of culture. The synthesis was initially intracytoplasmatic (data not shown) and then the fibrils appeared organized around the cells and became more evident.

All these data suggest that GM-CSF is able to induce cell differentiation of SaOS-2 cells. Since in the majority of cell systems, the increase in differentiation is associated with the beginning of apoptotic processes (Robbins et al., 1997), we decided to investigate if the same concentrations of the cytokine $(200 \mathrm{ng} / \mathrm{mL})$ able to trigger cell differentiation, were also able to induce apoptosis of SaOS-2 cells. It is evident that GM-CSF did not affect SaOS-2 apoptosis after 1 and 7 days of culture, as determined by flow cytometric analysis, whereas it significantly induced it after 14 days of culture, increasing both annexin $\mathrm{V}$ incorporation and propidium iodide staining in stimulated cells, thus doubling the percentage of apoptotic cells. This observation coincides with the major effect exerted by the cytokine on synthesis and differentiation. On the contrary, okadaic acid elicited a time-dependent increase in cell apoptosis, so confirming its function as an apoptotic inducing agent in SaOS-2 cells.

Extrinsic and intrinsic apoptotic pathways inducing cells to initiate and execute the cell death process have been identified (Green, 2000). The critical regulators of the intrinsic pathway are the Bcl-2 family members (Vander Heiden et al. 1999), among which $\mathrm{Bcl}-2$ and $\mathrm{Bcl}-\mathrm{XL}$ are the anti-apoptotic members (Gottlieb, 2000). Thus, to explore the mechanisms that might contribute to the GM-CSF induction of apoptosis, and to determine if they are related to down-regulation of the $\mathrm{Bcl}-2$ protein, we measured its levels by flow cytometric analysis. The results showed that the expression of $\mathrm{Bcl}-2$, either in the stimulated or unstimulated cells, did not change during the culture period. This suggests that GMCSF stimulated apoptosis in SaOS-2 cells was not associated with a down-regulation of this protein, and presumably was not mediated by this protein.

According to Duke et al. (1983), the analysis of endogenous endonuclease activity by agarose gel electrophoresis of DNA fragmentation shows the formation of a 200bp DNA ladder. This result is consistent with the activation of endogenous endonuclease which cleaves at interucleosomal sites and confirms that SaOS-2 treated cells were undergoing classical apoptosis.

On the other hand, we found that GM-CSF inhibited DNA synthesis in human SaOS-2 osteosarcoma cells after 14 days of culture, results which are consistent with the hypothesis that GM-CSF blocks SaOS-2 cell transit through the GI phase of the cell cycle. Here we showed that GM-CSF was able to trigger cell differentiation through in vitro mineralization and induce BSP-II, osteopontin and collagen I production. At the same time, GM-CSF is a cytokine that activates apoptosis of SaOS-2 cells in vitro after 14 days of culture at a concentration of $200 \mathrm{ng} / \mathrm{mL}$. This apoptotic pathway is not associated with a down-regulation of $\mathrm{Bcl}-2$ protein.

Our results suggest that GM-CSF stimulated a more mature osteoblastic phenotype in SaOS-2 cells and may be involved in the subsequent activation of cellular pro-apoptotic pathways. Further studies on the GM-CSF-induced apoptosis and its mechanism 
in the SaOS-2 cell line are required since they may shed new light on the biological aspects of this intriguing phenomenon. On the other hand, the identification of the signal transduction pathways involved in GM-CSF-induced apoptosis of SaOS-2 cells should open the way to a better understanding of the physiological control of bone cells in vivo.

\section{Acknowledgements}

The authors are grateful to Mr. Gennaro Fiumefreddo and Dr. Luca Vallefuoco for their invaluable technical assistance.

\section{References}

Abbas KA, Lichtman HA, Pober SA. In "Cellular and molecular immunology". Ed. W.B. Saunders Co. Philadelphia:1991. p. 241-2.

Aglietta M, Monzeglio C, Sanavio F, Aprà F, Morelli S, Stacchini A, et al. In vivo effect of human granulocyte-macrophage colony-stimulating factor on megakaryocytopoiesis. Blood 1991; 77:1191-4.

Bussolino F, Ziche X, Ming Wang J, Alessi D, Morbidelli L, Cremona O, et al. In vitro and in vivo activation of endothelial cells by colony stimulating factors. J Clin Invest 1991; 87:986-93.

Colotta F, Bussolino F, Polentarutti N, Guglielmetti PL, Sironi M, Bocchietto $E$, et al. Differential expression of the common $\beta$ and specific $\alpha$ chains of the receptors for GM-CSF, IL-3 and IL-5 in endothelial cells. Exp Cells Res 1993; 206:311-20.

Dedhar S, Gaboury L, Galloway P, Eaves C. Human granulocyte-macrophage colony-stimulating factor is a growth factor active on a variety of cell types of nonhemopoietic origin. Proc Natl Acad Sci USA 1988; 85:9253-7.

Duke R.C, Chervenak R, Cohen JJ. Endogenous endonuclease-induced DNA fragmentation: an early event in cell-mediated cytolysis. Proc Natl Acad Sci USA 1983; 80:6361-3.

Duvall E, Wyllie AH, Morris RG. Macrophage recognition of cells undergoing programmed cell death. Immunology 1985; 56: 351-5.

Duvall E, Wyllie AH. Death and the cell. Immunol Today 1986, 7:115-8.

Fadok VA, Voelker DR, Campbell PA, Cohen JJ, Bratton D.L, Henson PM. Exposure of phosphatidylserine on the surface of apoptotic lymphocytes triggers specific recognition and removal by macrophages. $J$ Immunol 1992; 148:2207-16.

Foulke RS, Marshall MH, Trotta PP, Von Hoff DD. In vitro assessment of the effects of granulocyte macrophage-colony stimulating factor on primary human tumors and derived lines. Cancer Res 1990; 50:62647.

Gottlieb RA. Mitochondria: execution central. FEBS Lett 2000; 482:612.

Graf K, Do YS, Ashizawa N, Meehan WP, Giachelli CM, Marboe CC, et al. Myocardial Osteopontin expression is associated with left ventricular hypertrophy. Circulation 1997; 96:3063-71.

Green DR. Apoptotic pathways: Paper wraps stone blunts scissors. Cell 2000; 102:1-4.

Kasugai S, Nagata T, Sodek J. Temporal studies on the tissue compartmentalization of bone sialoprotein (BSP), Osteopontin (OPN), and SPARC protein during bone formation in vitro. J Cell Physiol 1992 152:467-77.

Kinoshita T, Yokota T, Arai K, Miyajima A. Suppression of apoptotic death in hematopoietic cells by signalling through the IL-3/GM-CSF receptors. EMBO J 1995; 14:266-75.

Kittler LWE, McGrath H, Temeles D, Crittenden RB, Kister VK, and Quesenberry PJ. Biologic significance of constitutive and subliminal growth factor production by bone marrow stroma. Blood 1992; 79: 3168-78.

Le $X F$, Varela CR, Bast RC Jr. Heregulin-induced apoptosis. Apoptosis 2002; 7:483-91.

Martin SJ, Bradley JG, Cotter TG. HL-60 cells induced to differentiate towards neutrophils subsequently die via apoptosis. Clin Exp Immunol 1990; 79:448-53.

Metcalf D. The molecular control of cell division, differentiation, commit- ment and maturation in hematopoietic cells. Nature 1989; 339:27-30.

Muto A, Kizaki M, Kawamura C, Matsushita H, Fukuchi Y, Umezawa A, et al. A novel differentiation-inducing therapy for acute promyelocytic leukemia with a combination of arsenic trioxide and GM-CSF. Leukemia 2001; 15:1176-84.

Newmann SL, Henson JE, Henson PM. Phagocytosis of senescent neutrophils by human monocyte-derived macrophages and rabbit inflammatory macrophages. J Exp Med 1982; 156:430-4.

Nishijima I, Nakahata Y, Hirabayashi T, Inoue H, Kurata A, Miyajima N, et al. A human GM-CSF receptor expressed in transgenic mice stimulates proliferation and differentiation of hemopoietic progenitors to all lineages in response to human GM-CSF. Mol Biol Cell 1995; 6:497508.

Owen TA, Aronow M, Shaloub V, Barone LM, Wilming L, Tassinari MS, et al. Progressive development of the rat osteoblast phenotype in vitro: Reciprocal relationships in expression of genes associated with osteoblast proliferation and differentiation during formation of the bone extracellular matrix. J Cell Physiol 1990; 143:420-30.

Pistoia V. The biology of haematopoietic growth factors. Forum Trends Exp Clin Med 1995; 5.2(suppl.1):16-28.

Pockwinse S, Wilming L, Conlon D, Stein GS, Lian JB. Expression of cell growth and bone specific genes at single cell resolution during development of bone tissue-like organization in primary ostoblast cultures. J Cell Biochem 1992; 49:310-23.

Polak J M, Van Noorden S. In "An introduction to immunochemistry, current techniques and problems". Oxford University Press, Oxford, 1992.

Postiglione L, Di Domenico G, Montagnani S, Di Spigna G, Salzano S, Castaldo $C$, et al. Granulocyte-Macrophage Colony-Stimulating Factor (GM-CSF) induces the osteoblastic differentiation of the human osteosarcoma cell line SaOS-2. Calcified Tissue International 2003; 72:85-97.

Robbins SL, Cotran RA, Kumar V. Le basi patologiche delle malattie. V Ed. It. 1997, Piccin Editore:Padova, Italy.

Rodan S.B, Imai Y, Thiede M.A, Wesolowski G, Thompson D, Bar-Shavit $Z$, Shull S, Mann K, Rodan GA. Characterization of a Human Osteosarcoma Cell Line (SaOS-2) with osteoblastic properties. Cancer Res 1987; 47:4961-6.

Ruff MR, Farrar WL, Pert CB. Interferon- $\gamma$ and granulocyte/macrophage colony-stimulating factor inhibit growth and induce antigens characteristic of myeloid differentiation in small-cell lung cancer cell lines. Proc Natl Acad Sci USA 1986; 83:6613-7.

Sasano Y, Zhu J.X, Kamakura S, Mizoguchi I, Kagayama M.: Expression of major bone extracellular matrix proteins during osteogenesis in rat mandibles. Anat Embryol 2000; 202:31-7.

Savill JS, Wyllie AH, Henson JE, Walport MJ, Henson PE, Haslett C. Macrophage phagocytosis of aging neutrophils in inflammation: programmed cell death in the neutrophil leads to its recognition by macrophages. J Clin Invest 1989; 83:865-71.

Schmid C, Keller C, Gosteli-Peter M, Zapf J. Mitogenic and antiapoptotic effects of Insulin-like Growth Factor binding Protein- 6 in the human osteoblastic osteosarcoma cell line SaOS-2/B-10. Biochem Biophys Res Comm 1999; 263:786-9.

Schmitz B, Thiele J, Witte 0, Kaufman R, Wickenhauser C, Fisher R. Influence of cytokines (IL-1 $\alpha$, IL-3, IL-11, GM-CSF) on megakaryocyte-fibroblast interactions in normal human bone marrow. Eur J Haematol 1995; 55:24-32.

Schmitz B, Park IA, Kaufman R, Thiele J, Fischer R. Influence of cytokine stimulation (Granulocyte Macrophage-Colony Stimulating Factor, Interleukin-3 and Transforming Growth Factor Beta-1) on adhesion molecule expression in normal human bone marrow fibroblasts. Acta Haematol 1996; 94:173-81.

Shenolikar S. Protein phosphatase regulation by endogenous inhibitors. Cancer Biology 1995; 6:219-27.

Sonoda Y, Sakabe H, Ohimsono Y, Tanimukai S, Yokota S, Nakagawa S, et al. Synergistic actions of stem cell factor and other burst-promoting activities on proliferation of CD34+ highly purified blood progenitors expressing HLA-DR or different levels of c-kit protein. Blood 1994; 84:4099-106.

Taichman RA, Emerson SG. Human osteosarcoma cell lines MG-63 and SaOS-2 produce G-CSF and GM-CSF: identification and partial characterization of cell-associated isoforms. Exp Hematol 1996; 24:50917.

Vander Heiden M.G, Thompson C.B.: Bcl-2 proteins; regulators of apoptosis or of mitochondrila homeostasis? Nat Cell Biol 1999; 1:E209216.

Wyllie AH, Kerr JFR, Currie AR. Cell death: the significance of apoptosis. Int Rev Cytol 1980, 68:251.

Wyllie AH. Glucocorticoid-induced thymocyite apoptosis is associated with endogenous endonuclease activation. Nature 1980; 284:555. 